\title{
DEVELOPING A TEXTBOOK WITH BIG BOOK MEDIA BASED BASAL READERS METHOD TO IMPROVE EARLY READING AT LOW CLASSES
}

\author{
Yani Agustiningrum ${ }^{1}$, Slamet Utomo ${ }^{2}$, Irfai Fathurrohman ${ }^{3}$ \\ 1,2,3 UMK Kudus, Indonesia \\ 1*yaniagusti85@gmail.com
}

\begin{abstract}
This study aimed to develop a basal readers method with Big Book media for educators and first grade students which was valid, practical, and effective. The development process was carried out based on Borg \& Gill model which emphasized the context of needs (educators and students) so that a textbook for early reading skills could be produced through Big Book media based Basal Readers method. The results of the validity test, which was obtained from the validation of content, language, presentation, graphics, found that the total percentage was $93.10 \%$ with Very Valid category. Then, the results of the questionnaire revealed that the percentage of the teacher's response was $90.25 \%$ and for the students' responses was $87.22 \%$ while the effectiveness of early reading based on the $t$-test showed that the value of t count $>$ t table $=5.458>2.414$. It was concluded that the textbook with big book media based basal readers method was feasible to be used in early reading at the lower grades of elementary school.
\end{abstract}

Keywords: basal readers method, big book media, beginner reading

\section{PENGEMBANGAN BUKU AJAR DENGAN METODE BASAL READERS BERBASIS MEDIA BIG BOOK UNTUK MENINGKATKAN MEMBACA PERMULAAN KELAS RENDAH}

\begin{abstract}
ABSTRAK
Penelitian ini bertujuan untuk menghasilkan proses pengembangan metode basal readers dengan media Big Book untuk pendidik dan peserta didik kelas satu yang valid, praktis, dan efektif. Pengembangan dilakukan berdasarkan model Borg \& Gill yang menekankan pada konteks kebutuhan (pendidik dan peserta didik) sehingga dihasilkan bahan ajar keterampilan membaca permulaan dengan metode basal readers berbasis media Big Book. Berdasarkan hasil uji coba kevalidan dapat dilihat dari validasi isi, bahasa, penyajian, kegrafikaan, keseluruhan $93.10 \%$ dengan kategori sangat valid Hasil kuesioner dilihat dari respon guru, 90.25\% respon siswa $87.22 \%$ sedangkan efektifitas membaca permulaan berdasarkan uji-t didapatkan hasil nilai t hitung $>\mathrm{t}$ tabel $=5.458>2.414$. Dapat disimpulkan bahwa pengembangan metode basal readers membaca permulaan menggunakan media Big Book yang dikembangkan layak digunakan dalam membaca permulaan di kelas rendah sekolah dasar.
\end{abstract}

Kata Kunci: metode basal readers, media big book, membaca permulaan

\begin{tabular}{|c|c|c|}
\hline Submitted & Accepted & Published \\
\hline 22 Maret 2021 & 09 Agustus 2021 & 14 September 2021 \\
\hline
\end{tabular}

\begin{tabular}{|l|c|c|}
\hline Citation & $:$ & $\begin{array}{r}\text { Agustiningrum, Y., Utomo, S., \& Fathurrohman, I. (2021). Developing a Textbook with Big Book Media Based Basal } \\
\text { Readers Method to Improve Early Reading at Low Classes. Jurnal PAJAR (Pendidikan dan Pengajaran), 5(5), } \\
1163-1169 . \text { DOI : http://dx.doi.org/10.33578/pjr.v5i5.8380. }\end{array}$ \\
\hline
\end{tabular}

\section{PENDAHULUAN}

Dalam rangka menumbuhkan kebiasaan dan kegemaran membaca pada suatu masyarakat perlu dimulai secara bertahap. Salah satu langkah awal dalam menumbuhkan kebiasaan dan kegemaran membaca dalam masyarakat adalah melalui kebiasaan membaca pada jenjang sekolah. Melalui proses pembelajaran di SD, siswa diharapkan memperoleh dasar-dasar kemampuan membaca disamping kemampuan menulis dan menghitung serta kemampuan yang lainnya. Dengan dasar kemmapuan itu, siswa dapat menyerap berbagai pengetahuan yang sebagian besar disampaikan melalui tulisan.

Keterampilan membaca dan menulis, khususnya keterampilan membaca harus segera dikuasai oleh siswa di SD karena keterampilan ini secara langsung berkaitan dengan seluruh proses belajar mengajar siswa di sekolah. Keberhasilan 
belajar siswa dalam mengikuti proses kegiatan belajar-mengajar di sekolah sangat ditentukan oleh penguasaan kemampuan membaca mereka. Siswa yang tidak mampu membaca dengan baik akan mengalami kesulitan dalam mengikuti kegiatan pembelajaran untuk semua mata pelajaran. Siswa akan mengalami kesulitan dalam menangkap dan memahami informasi yang disajikan dalam berbagai buku pelajaran, bukubuku bahan penunjang, dan sumber-sumber belajar tertulis yang lain. Akibatnya, kemajuan belajarnya juga lamban jika dibandingkan dengan teman-temannya yang tidak mengalami kesulitan dalam membaca. Menurut Santosa (2009:3.19) melalui pembelajaran di SD siswa diharapkan memperoleh dasar-dasar kemampuan membaca disamping kemampuan menulis dan menghitung, serta kemampuan esensial lainnya, dengan dasar kemampuan tersebut siswa akan dapat menyerap berbagai pengetahuan yang sebagian besar disampaikan melalui tulisan.

Menurut Jamaris (2014:133) membaca merupakan suatu kegiatan yang bersifat kompleks karena kegiatan ini melibatkan kemampuan dalam mengingat simbol-simbol grafis yang berbentuk huruf, mengingat bunyi dari simbol-simbol tersebut dan menulis simbol-simbol grafis dalam rangkaian kata dan kalimat yang mengandung makna.

Menurut Tarigan (2008:1) pemeblajaran bahasa Indonesia mencakup empat aspek keterampilan yaitu keterampilan mendengarkan, berbicara, membaca, dan menulis. Menurut Tarigan dalam Taufiina (2015:153) membaca adalah proses yang dilakukan serta digunakan oleh pembaca untuk memperoleh pesan yang hendak disampaikan oleh penulis melalui media kata-kata/ bahasa tulis terutama dalam membaca permulaan. Membaca permulaan merupakan salah satu jenis kegiatan membaca dan harus dilakukan dengan teknik awal yang baik dan benar. Kelancaran dan ketepatan anak membaca pada tahap belajar membaca permulaan dipengaruhi oleh keaktifan dan kreativitas guru yang mengajar di kelas rendah. Dengan kata lain, guru memegang peranan yang strategis dalam meningkatkan keterampilan membaca siswa. Peranan strategis tersebut menyangkut peran guru sebagai fasilitator, motivator, sumber belajar, dan organisator dalam proses pembelajaran.

Penggunaan metode Basal Readers dalam pembelajaran membaca di kelas awal, merupakan salah satu alternatif dalam membantu atau membimbing siswa kearah penemuan sendiri, yaitu dengan menggunakan alat peraga/ media. Metode basal readers atau membaca awal merupakan serangkaian aktivitas membaca yang dilakukan anak setelah ia mengenal dan memahami berbagai bentuk huruf dan berbagai rangkaian variasi gabungan huruf menjadi berbagai kata. Isi bacaan buku dimulai dari konsep-konsep yang konkret kepada konsepkonsep yang abstrak, atau konsep-konsep yang sudah dikenal anak kepada konsep-konsep yang sulit dan abstrak. Pada prosesnya dibutuhkan alat peraga/media yang konkrit guna mempermudah siswa melaksanakan proses pembelajaran. Adapun media penunjang yang dimaksud berupa media big book. Menurut USAID (2014:19) media big book merupakan buku jenis bacaan yang di dalamnya terdapat gambar, tulisan, ataupun ukuran dalam skala besar. Big book berkarakteristik khusus yang dibesarkan, baik teks maupun gambarnya. Ukuran media big book bervariasi mulai dari kertas A3, A4 dan A5 atau masing-masing disesuaikan dengan kebutuhan. Guru juga dapat merancang sendiri big book yang isi dan ceritanya dapat disesuaikan dengan karakteristik, minat dan kebutuhan peserta didik. Sehingga memungkinkan terjadinya kegiatan membaca bersama antara guru dan siswa. Dengan penggunaan Big Book guru dapat memilih isi cerita yang disesuaikan dengan tema dalam pembelajaran, selain itu Big Book dapat digunakan sebagai model dalam membaca dan menulis permulaan (Muhammad Aulia, 2019:964).

Berdasarkan studi pendahuluan yang peneliti lakukan di SDN Dabin 3 Kecamatan Donorojo Kabupaten Jepara, proses pembelajaran berlangsung kurang optimal, diantaranya 1) kurangnya motivasi peserta didik dalam membaca, disebabkan pembelajaran masih berpusat pada pendidik, 2) pendidik jarang menggunakan media dalam proses pembelajaran, 3) terdapat peserta didik yang belum lancar membaca, 4) belum adanya stimulus khusus pengembangan membaca permulaan yang sesuai dengan kebutuhan peserta 
didik, 5) rendahnya kualitas proses pembelajaran terkait erat dengan buku ajar yang digunakan pendidik, seperti tidak adanya kreatifitas pendidik mencari materi tambahan yang sesuai kebutuhan peserta didik.

Pemasalahan keterampilan membaca permulaan diatas, juga didukung oleh hasil penelitian terdahulu dari Rachmawaty, M. (2017) berjudul "Peningkatan Kemampuan Membaca Permulaan Melalui Dinding Kata (Word Wall)" menjelaskan permasalahan penyebab kemampuan membaca permulaan anak masih rendah, hal ini dikarenakan belum adanya stimulasi khusus pengembangan kemmapuan membaca permulaan yang sesuai dengan tahapan dan kebutuhan anak, dan pelaksanaan kegiataan membaca permulaan masih bersifat satu arah, yaitu guru yang bertindak sebagai pusat kegiatan. Ratih (2019) berjudul "Pengembangan Bahan Ajar Membaca permulaan Dalam Pembelajaran Tematik Dengan Model VARK di Kelas 1 Sekolah Dasar" menjelaskan kurangnya motivasi peserta didik dalam membaca, disebabkan pembelajaran berpusat pada pendidik, kurangnya peserta didik memperoleh pengalaman langsung baik mengamati, menanya, mencobakan, mengolah informasi, dan mengkomunikasikan kemudian pendidik menyampaikan materi hanya satu arah dan tidak ada umpan balik terhadap peserta didik.

Untuk mengatasi permasalahan yang telah dikemukakan, perlu dilakukan pengembangan buku ajar secara efektif dan kreatif serta berorientasi pada pembelajaran membaca permulaan yaitu dengan metode basal readers dengan bantuan media Big Book. Metode ini bertujuan untuk mengenalkan dan memahami kosakata kepada peserta didik dimulai dari konsep konkret ke abstrak. Sehingga peserta didik mampu memahami arti dari sebuah kata. Basal readers atau membaca awal merupakan serangkaian aktivitas membaca yang dilakukan anak setelah ia mengenal dan memahami berbagai bentuk huruf dan berbagai rangkaian variasi gabungan huruf menjadi berbagai kata. (Jamaris, 2014:146). Basal reader dikenal dengan pendekatan berbasis kemampuan atau pendekatan bottom-up. Proses membaca dibagi kedalam beberapa rangkaian subskills yang harus diajarkan dalam urutan yang telah ditentukan. Komponen utama dalam pendekatan ini adalah seri bacaan berjenjang yang dikenal dengan basal reader series (Donoghue, 2009:164).

Pelaksanaan pembelajaran menggunakan metode Basal Readers ini ada beberapa tahap yang harus dilakukan, sesuai dengan yang dikemukakan Estille (1988:308) yaitu 1) Persiapan, memberikan motivasi kepada siswa, menyepakati bersama tujuan dari membaca dan memberikan informasi yang dibutuhkan siswa untuk memahami cerita secara utuh, 2) membaca terbimbing, menafsirkan gambar, membaca nyaring, membaca dalam hati, dan pemahaman cerita merupakan kegiatan yang bisa dilakukan dalam tahap ini, 3) latihan, guru memberikan latihan dan kegiatan yang bertujuan mengembangkan kosakata, latihan dapat berupa teka-teki silang, soal isian singkat, permainan, dan 4) tindak lanjut, dalam tahap ini siswa melaksanakan kegiatan secara mandiri, guru dapat memberikan tugas siswa untuk membaca di perpustakaan.

Menurut Lynch dalam Handayani (2019:3) "Big book is a book which has a big size as well as font. Due to the size which is different from ordinary books. Big book can be seen easily from all part of the class. Besides it has also colourful series pictures inside to help students became more understand about the content of the story or even stimulate students imagination". Big Book adalah buku yang memiliki ukuran dan tulisan besar. Karena ukurannya berbeda dari buku biasa. Big Book dapat dilihat dengan mudah dari semua bagian kelas. Selain itu juga terdapat gambar seri berwarna-warni untuk membantu siswa menjadi lebih memahami tentang isi cerita atau bahkan merangsang imajinasi siswa. Ukuran Big book bisa beragam, misalnya ukuran A3, A4, A5, atau seukuran koran. Ukuran Big Book harus mempertimbangkan segi keterbacaan seluruh siswa di kelas.

Berdasarkan paparan diatas, peneliti tertarik untuk mengembangkan metode membaca permulaan dengan judul "Pengembangan Metode Basal Readers Berbasis Media Big Book Untuk Meningkatkan Kemampuan Membaca Permulaan Kelas Rendah". 


\section{METODE PENELITIAN}

Desain penelitian dan pengembangan (Research and Development) yang digunakan dalam pengembangan metode basal readers ini adalah dengan menggunakan $\mathrm{R} \& \mathrm{D}$ yang disusun oleh Walter R. Borg dan Meredith D.Gall. Pendekatan sistem ini dikenal dengan nama "Model Pengembangan Borg \& Gall". Penelitian dan pengembangan model ini pada dasarnya merupakan suatu proses yang digunakan untuk mengembangkan dan memvalidasi produk yang dikembangkan. Menurut Borg dan Gall dalam Sugiyono (2016:35) pelaksanaan strategi penelitian dan pengembangan terdiri dari dari sepuluh langkah yaitu 1) potensi dan masalah, 2) pengumpulan data, 3) desain produk, 4) validasi desain, 5) revisi desain, 6) uji coba produk, 7) revisi produk, 8) uji coba pemakaian, 9) revisi produk, dan 10) produksi massal.

Prosedur penelitian yang dilakukan peneliti dalam pengembangan ini diadaptasi dari langkah-langkah pengembangan yang dikembangkan oleh Borg \& Gall tersebut dengan pembatasan. Borg \& Gall (dalam Emzir, 2013: 271) menyatakan bahwa dimungkinkan untuk membatasi penelitian dalam skala kecil, termasuk membatasi langkah penelitian. Penerapan langkahlangkah pengembangan disesuaikan dengan kebutuhan peneliti. Mengingat keterbatasan waktu dan dana yang dimiliki oleh peneliti, maka langkah-langkah tersebut disederhanakan menjadi tujuh langkah pengembangan.

\section{HASIL DAN PEMBAHASAN}

Pengembangan pada penelitian ini dalam bentuk buku tentang membaca permulaan yaang digunakan secara klasikal sekolah. Buku ini berisi tentang keterampilan membaca permulaan yang berbentuk buku yang ditujukan kepada siswa kelas 1. Pembelajaran membaca permulaan merupakan tingkatan proses pembelajaran membaca untuk menguasai sistem tulisan sebagai representasi visual bahasa (Syafi'ie, 1999:16).

Penyajian data pada penelitian dan pengembangan metode basal readers berbasis media big book ini dibedakan menjadi 3 jenis yaitu: (1) kebutuhan metode basal readers berbasis media big book, (2) pengembangan metode Basal
Readers berbasis media big book, dan (3) keefektifan metode basal readers berbasis media big book, dapat dijelaskan sebagai berikut:

1) Kebutuhan Metode Basal Readers berbasis Media Big Book

Tingkat kebutuhan diperoleh dengan menggunakan pedoman observasi, wawancara terhadap guru dan siswa, serta angket yang ditujukan kepada guru. Lembar observasi ini berbentuk checklist. Observasi terhadap siswa digunakan untuk mengetahui fakta kondisi siswa saat pembelajaran. Aspek-aspek yang akan diamati diantaranya: 1) keaktifan siswa, 2) siswa mampu melaksanakan tugas dari guru, 3) interaksi siswa dengan guru dan temannya, 4) sikap siswa selama pembelajaran. Berdasarkan data yang diperoleh dari keempat sekolah adalah, SD Negeri 6 Blingoh rata-rata 2.48, SD Negeri 2 Blingoh rata-rata 2.5, SD Negeri 1 Jugo rata-rata 2.37, dan SD Negeri 3 Jugo rata-rata 2.33. Sehingga dapat disimpulkan bahwa rata-rata dari keempat SD memperoleh nilai kurang dari 3 dengan kategori cukup. Secara keseluruhan dari hasil observasi pada saat pembelajaran menunjukkan siswa yang belum aktif, strategi dan metode pembelajaran yang dilaksanakan guru kurang menarik sehingga minat belajar siswa kurang.

Hasil observasi diperkuat dengan wawancara terhadap siswa untuk mengetahui kebutuhan media pembelajaran yang mampu membuat siswa aktif, semangat dan minat siswa untuk belajar membaca permulaan. Dari aspek kebutuhan materi dan isi, siswa jarang sekali mendapatkan pembelajaran membaca permulaan yang sesuai dengan kurikulum 2013. Materi yang diberikan hanya dari buku siswa dan LKS yang membuat siswa kurang semangat dan bosan dalam belajar membaca permulaan. Sedangkan dari aspek grafis, dalam belajar membaca permulaan tulisan yang ada dalam buku berukuran kecil, tidak ada gambarnya, dan kurang berwarna sehingga siswa kurang semangat.

Lembar observasi terhadap guru memuat kriteria diantaranya: 1) Guru membuka pembelajaran dengan baik, 2) Guru menstimulus siswa untuk bertanya dan berani berpendapat, 3) Guru dapat menciptakan pembelajaran yang aktif dan menyenangkan, 4) Guru menggunakan metode 
pembelajaran yang menarik, 5) Guru menutup pelajaran dengan baik. Data hasil observasi kebutuhan dari semua aspek dari 4 SD diperoleh nilai yaitu SD N 6 Blingoh 2.4, SD N 2 Blingoh 2.3, SD N 1 Jugo 2.4, dan SD N 3 Jugo 2.6. Dari data tersebut dapat disimpulkan bahwa rata-rata dari keempat SD memperoleh nilai kurang dari 3 dengan kategori cukup. Hal ini menunjukkan bahwa guru dalam melaksanakan pembelajaran membaca permulaan di sekolah masih membutuhkan buku-buku yang berisi materi yang menarik dengan strategi dan metode pembelajaran yang mampu menciptakan pembelajaran yang aktif dan menarik.

Hasil observasi diperkuat dengan wawancara dengan guru kelas satu di SD Negeri 6 Blingoh, SD Negeri 2 Blingoh, Sd negeri 1 Jugo, dan SD Negeri 3 Jugo. Wawancara meliputi aspek kebutuhan materi, isi, dan grafis media pembelajaran. Pada aspek materi, dalam pembelajaran membaca permulaan guru masih membutuhkan buku yang materinya mudah dipahami siswa, pada aspek isi, yang dibutuhkan guru adalah buku yang memiliki isi pembelajaran yang menarik, dan jelas agar mudah dibaca siswa. Sedangkan dalam aspek kebutuhan grafis media pembelajaran, guru berpendapat agar buku memiliki tulisan yang besar, jarak yang tidak terlalu dekat, berwarna dan memiliki gambar yang menarik siswa dengan karakter sesuai anak kelas satu kelas rendah.

2) Pengembangan Metode Basal Readers Berbasis Media Big Book

Pengembangan metode basal readers dengan berbasis media big book untuk meningkatkan kemampuan membaca permulaan pada kelas rendah ini menggunakan langkahlangkah pengembangan Borg \& Gall yang penjelasannya diuraikan sebagai berikut : a) Potensi dan Masalah, dalam pelaksanaan pembelajaran guru belum melakukan pembelajaran yang konstekstual, guru belum menggunakan metode pembelajaran dalam membimbing siswa belajar membaca, dan guru belum menggunakan media pembelajaran yang menarik minat siswa untuk aktif dan semangat dalam belajar membaca permulaan. b) Pengumpulan Data, dilakukan dengan mengumpulkan informasi terkait literatur tentang ruang lingkup produk melalui studi pustaka. Studi pustaka ini dilakukan melalui sumber dari buku, jurnal, artikel karya ilmiah, dan penelitian-penelitian yang sudah ada. Sedangkan studi lapangan dilakukan dengan observasi, wawancara, dan penyebaran angket di SD Negeri 6 Blingoh, SD Negeri 2 Blingoh, SD Negeri 1 Jugo, dan SD Negeri 3 Jugo. c) Desain Produk Pengembangan, produk dikembangkan dengan karakteristik yang menarik dan menyenangkan untuk belajar membaca permulaan. Dalam pengembangan buku ini kemenarikan ditinjau dari komponen isi, desain fisik, desain teks, dan desain visual. d) Validasi Ahli Materi dan Media, hasil validasi ahli dari aspek materi dalam buku membaca permulaan dan media big book memperoleh skor 86 rata-rata 4.3 persentase $86 \%$ dengan kategori sangat baik. Sehingga dapat disimpulkan buku membaca permulaan dan media big book yang dikembangkan layak dan baik secara materi untuk digunakan dalam pembelajaran membaca permulaan dan diujicobakan. Sedangkan hasil validasi ahi media memperoleh jumlah skor 91 rata-rata 3.64 persentase $91 \%$ dengan kategori sangat baik. Hal tersebut ditunjukan dari kesesuaian dengan materi ajar, desain sampul yang menarik dan secara keseluruhan produk menarik. Sehingga dapat disimpulkan bahwa media dikatakan layak sebagai sumber belajar. e) Revisi Desain Produk, pada bagian revisi produk secara keseluruhan sudah layak digunakan untuk dipakai penelitian dan sebagai salah satu sumber belajar membaca permulaan.

Setelah dilakukan uji coba produk, buku membaca permulaan dan media big book tidak ada revisi. Buku metode basal readers dan media big book sudah dibuat menarik dengan beragam warna dan gambar yang sesuai dengan karakteristik siswa kelas rendah. Cara menggunakan produk ini juga mudah, karena penulisan buku menggunakan metode membaca permulaan. Sehingga guru ataupun siswa tidak kesulitan dalam belajar membaca permulaan

3) Keefektifan Metode Basal Readers Berbasis Media Big Book

Untuk menguji dan mendeskripsikan keefektifan metode basal readers berbasis media 
big book dilakukan uji coba produk dengan memberikan perlakuan kepada kelompok eksperimen. Hasil penilaian belajar membaca permulaan siswa diperoleh dengan memberikan skor pada rubrik penilaian siswa. Nilai rata-rata pada kelompok eksperimen adalah 77.25 nilai tertinggi mendapat 95 dan nilai terendah mendapat 60. Nilai rata-rata pada kelompok kontrol adalah 56.95 nilai tertinggi mendapat 85 dan nilai terendah 35. Dari rata-rata nilai tersebut menunjukkan bahwa penggunaan metode basal readers berbasis media big book efektif digunakan dalam pembelajaran membaca permulaan.

Untuk mendeskripsikan keefektifan metode basal readers berbasis media big book untuk meningkatkan membaca permulaan dilakukan uji prasyarat dan uji-t. Uji prasyarat dilakukan untuk melihat data berdistribusi normal atau tidak dan kelompok homogen atau tidak. Uji Normalitas diketahui nilai Sig. Kelompok eksperimen sebesar 0.102 dan kelompok kontrol 0.026 . Karena nilai kelompok eksperimen tersebut $>0.05$ maka disimpulkan bahwa data hasil belajar kelompok eksperimen terdistribusi normal dan karena nilai kelompok kontrol $<0.05$ maka disimpulkan bahwa data hasil belajar kelompok terdistribusi tidak normal. Uji homogenitas diketahui nilai signifikasi (Sig.) hasil pembelajaran membaca permulaan kelompok eksperimen dan kelompok kontrol sebesar 0.515 karena $0.515>$ 0.05 maka disimpulkan bahwa varian data hasil membaca permulaan pada kelas eksperimen dan kelas kontrol adalah sama atau homogen.

Sedangkan untuk uji-t, diketahui nilai ratarata kelas eksperimen 77.4 dan kelompok kontrol 56.42 sehingga secara deskriptif analisis ada perbedaan rata-rata hasil belajar kelompok eksperimen dan kelompok kontrol. Diketahui nilai $\mathrm{T}$ hitung sebesar 5.458 sedangkan nilai $\mathrm{t}$ tabel yang dicari dengan rums $(\mathrm{q} / 5) ; \mathrm{df}=(0.05 / 2) ; 44=0.01$; 34 dengan nilai sebesar 2.414. Dengan demikian nilai $\mathrm{t}$ hitung $>\mathrm{t}$ tabel $=5.458>2.414$, berdasarkan dasar pengambilan keputusan perbandingan dapat disimpulkan Ho ditolak dan Ha diterima dengan asumsi terdapat perbedaan signifikan hasil belajar dengan media pembelajaran yang berbeda.

Untuk mengetahui keefektifan metode basal readers berbasis media big book juga dapat dilihat dari kuesioner respon guru dan siswa. Hasil kuesioner respon guru kelas satu SD dabin 3 Kecamatan Donorojo Kabupaten Jepara memperoleh skor 722 rata-rata 36.1 persentase 90.25\% dengan kategori sangat baik. Sedangkan untuk kuesioner hasil tanggapan siswa memperoleh skor 314 rata-rata 10.46 persentase $87.22 \%$ dengan kategori baik. Hal ini menunjukkan bahwa buku metode basal readers berbasis media big book dapat membantu siswa dalam belajar membaca permulaan. Siswa merasa senang belajar menggunakan produk pengembangan ini.

\section{SIMPULAN DAN REKOMENDASI}

Berdasarkan hasil penelitian pengembangan metode basal readers berbasis media big book untuk meningkatkan kemampuan membaca permulaan siswa kelas rendah sekolah dasar dapat disimpulkan bahwa analisis kebutuhan guru dan siswa terhadap pengembangan metode basal readers berbasis media big book dilakukan melalui observasi, wawancara, dan angket.

Pengembangan metode basal readers berbasis media big book menggunakan metode Borg \& Gall dengan langkah 1) identifikasi potensi masalah, 2) pengumpulan data, 3) desain produk, 4) validasi desain, 5) revisi desain, 6) uji coba produk, dan 7) revisi produk. Pengembangan produk pada penelitian ini terdiri dari buku membaca permulaan metode basal readers dan media big book. Untuk pengembangan metode basal readers melalui buku membaca permulaan yang terdiri dari empat seri. Buku ini juga dilengkapi dengan gambar yang membantu siswa untuk memahami kata dari konsep konkret ke konsep yang abstrak. Sedangkan untuk media big book, isi sama dengan buku tersebut, hanya gambar dan tulisan diperbesar. Media ini dimaksudkan untuk membantu guru dan siswa membaca bersama-sama secara terbimbing. Setelah dikembangkan produk ini diuji kelayakannya melalui uji validasi ahli yang memperoleh skor dengan kategori sangat baik.

Hasil uji efektifitas menunjukkan bahwa metode basal readers berbasis media big book efektif digunakan dalam membaca permulaan kelas rendah. Data dari uji $t$ menunjukkan $t_{\text {hitung }}>$ 
$\mathrm{t}_{\text {tabel }}$ yaitu $5.458>2.414$, maka dapat disimpulkan Ho ditolak dan Ha diterima dengan asumsi terdapat perbedaan signifikan hasil belajar dengan media pembelajaran yang berbeda. Keefektifan metode basal readers berbasis media big book juga diperkuat dengan hasil angket respon guru dan siswa kelas I SD dabin 3 Kecamatan Donorojo Kabupaten Jepara. Hasil respon guru memperoleh skor 722 rata-rata 36.1 persentase $90.25 \%$ dengan kategori sangat baik. Untuk hasil angket tanggapan siswa diperoleh jumlah skor 314 ratarata 10.46 persentase $87.22 \%$ dengan kategori sangat baik.

Hasil efektivitas peserta didik menunjukkan bahwa pengembangan metode basal readers berbasis media big book untuk meningkatkan membaca permulaan di kelas rendah telah dinyatakan efektif dan telah meningkatkan membaca permulaan dan layak digunakan. Sehingga dengan metode basal readers berbasis media big book memperkuat bahwa pengembangan metode ini layak digunakan.

\section{DAFTAR PUSTAKA}

Aulia, M. (2019). Penggunaan Big Book Dalam Pembelajaran Membaca Permulaan Di Sekolah Dasar. Jurnal Basicedu, 3 (3), 963-969.

Estill, A. J (ed). (1988). Teaching Reading 3rd ed. USA: Scott Foresman and Company.

Handayani, S. (2019). Upaya Meningkatkan Keterampilan Literasi Awal Melalui Media Big Book. Prosiding Seminar Nasional. 1-7.

Jamaris, M. (2014). Kesulitan Belajar: Perspektif, Assesmen, dan Penanggulangannya Bagi Anak Usia Dini dan Usia Sekolah. Bogor: Ghalia Indonesia.

Muchlisoh. (1992). Materi Pokok Bahasa Indonesia 3. Jakarta: Depdikbud.

Nurhadi. (2016). Teknik Membaca. Jakarta: PT Bumi Aksara.

Nurjani. (2018). Literasi Pada Pembelajaran Menulis Bagi Anak Sekolah Dasar. Jakarta: Pena.

Musfiroh, T. (2009). Baca Tulis untuk Usia Dini. Bandung: PT. Refika Aditama.
Rachmawaty, M. (2017). Peningkatan Kemampuan Membaca Permulaan Melalui Dinding Kata (Word Wall). Jurnal Ilmiah Pendidikan Prasekolah dan Sekolah Awal, 1, 28-44.

Rahim, F. (2008). Pengajaran Membaca Di Sekolah Dasar. Jakarta: Sinar Grafika.

Rahmawati. (2017). Strategi Pembelajaran Membaca dan Menulis Permulaan Melalui Media Kata Bergambar. Jurnal SAP, 1(3), 17- 25

Ratih, M. (2019). Pengembangan Bahan ajar Membaca Permulaan Dalam Pembelajaran Tematik Dengan Model VARK Di Kelas 1 Sekolah Dasar. Jurnal Basicedu, 3(2), 498507.

Santosa, P, dkk. (2009). Materi dan Pembelajaran Bahasa Indonesia SD. Jakarta: Universitas Terbuka.

Syafi'ie, I. (1999). Terampil Berbahasa Indonesia 1: Petunjuk Guru Bahasa Indonesia. Jakarta: Balai Pustaka.

Tarigan, H. G. (2008). Menyimak Sebagai Suatu Keterampilan Berbahasa. Bandung. Angkasa. 